Historic, archived document

Do not assume content reflects current scientific knowledge, policies, or practices. 



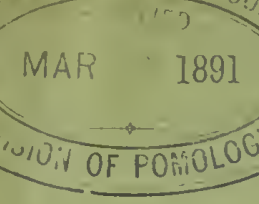

\section{CATALOGUE}

OF

\section{SherwOOd HaLl NurSERIES

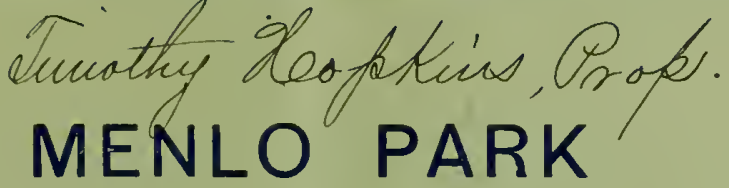

\section{SAN MATEO COUNTY}

CALIFORNIA

1891 



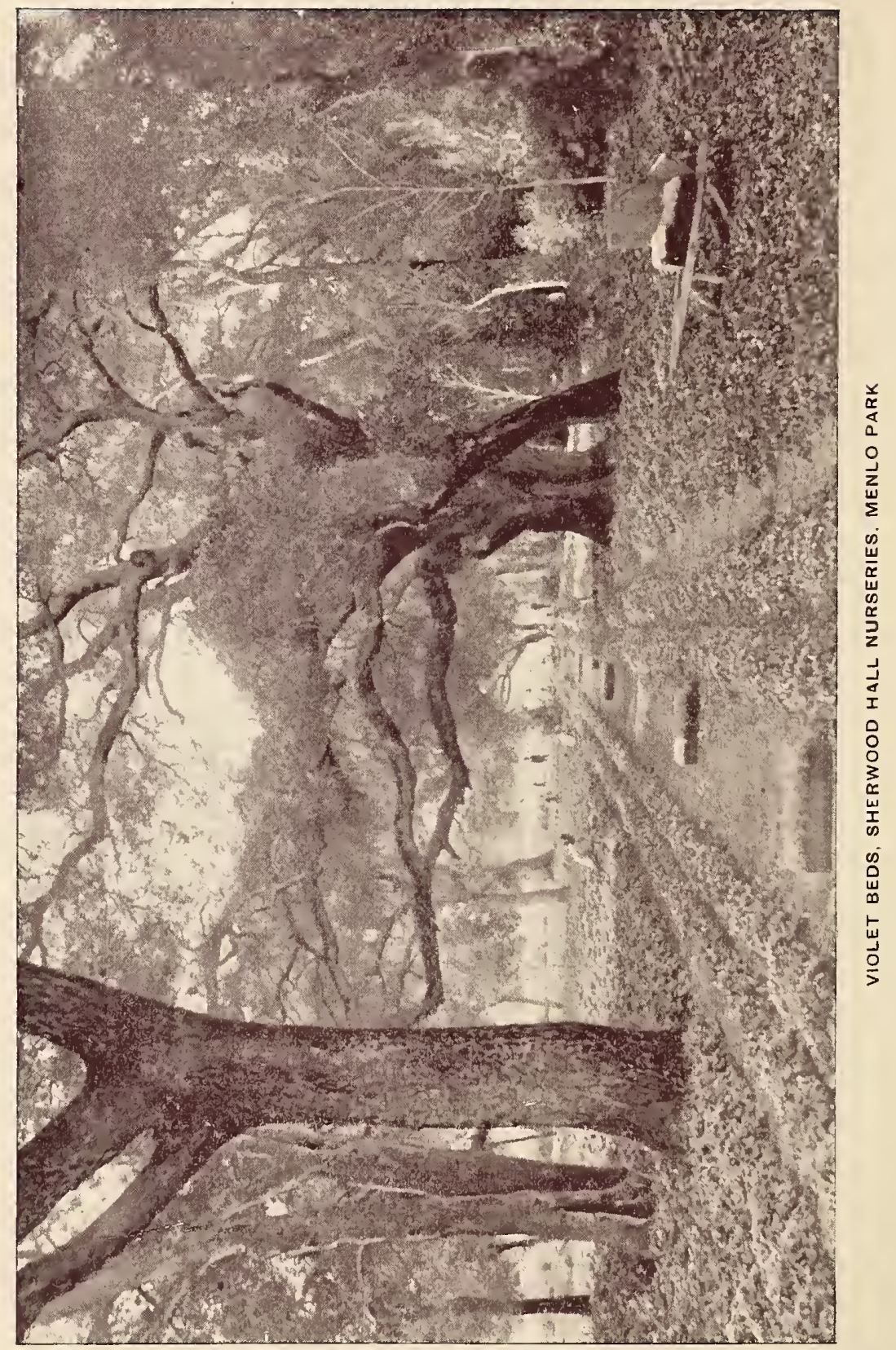




\section{Please Read Carefully}

I

T IS WITI PLEASURE that we present this, our first catalogue, and those who favor us with their orders may feel assured that every endeavor will be made to comply with all demands in such a prompt and satisfactory manner as to assure a continuation of their favors.

THE NURSERY.-Our Nursery is located at Menlo Park, San Mateo County, on the Southern Pacific Railroad midway between San Francisco and San Jose.

STOCK.-All stock offered is strong and healthy, true to name and free from insect pests. Constant watchfulness is exercised to prevent the propagation of weak or imperfect stock and varieties have been selected with a special view to their adaptation to the soil and climate of California.

PACKING.-All orders are packed by those experienced in the art, and so carefully are plants prepared for shipment that complaints from bad packing are exceedingly rare.

PRICES.-No attempt is made to outdo other establishments in prices. It costs money to grow good stock and we have no other kind for sale. So-called cheap stock generally proves very dear in the end. Prices have been made as reasonable as possible, quality of stock considered. Special prices will be made for large orders.

SHIPPING.-Plants should, whenever practicable, be sent by express, as larger, stronger stock can be given, but every care will be exerciced in selecting stock and in packing mail orders for points not accessible by express.

MISTAKES.-The greatest pains are taken to prevent mistakes in filling orders, but should any be detected, prompt notice of the fact and circumstance will assure correction without delay.

CORRECT ADDRESS.-Be careful to write your orders and full name and address very plainly; attention to this will obviate much confusion, delay and possible loss.

SMALL ORDERS.-As the expense attending the packing of small orders is often nearly or quite as great as that attending those of greater size and value, patrons are requested to add 10 cents for packing on all plant orders of a less value than $\$ 1$.

REMIT'TANCES.-Money should be sent by Wells, Fargo Express or Post-Office money order, drawn on San Francisco.

\section{SHERWOOD HALL NURSERIES,} TIMOTHY HOPKINS, Proprietor, Menlo Park, California. 


\section{CALIFORNIA GARDENS}

Where in all the world can there be found more beautiful gardens than in California, where the rose, the palm and the lily vie with one another in luxuriant beauty, where the magnolia and the modest violet unburden their sweetness upon caressing breezes, where the rich foliage and brighthued blossoms of the tropics, the feathery bamboo and gorgeous peony of the Orient, and the graceful, many-hued flowers of temperate climes, all find a congenial home under the same bright skies and in the same kindly soil?

Given such lavish possibilities, the man is indeed ungrateful who does not plant and cultivate these, earth's brightest treasures. But there are in California homes without flowers, whose door-posts have never known the twining honeysuckle or drooping rose, whose yards are barren deserts compared to the bright-clad hillsides of nature's fashioning. There are children to whom the simplest flowers are unknown. There are women of gentle birth, who, surrounded by fertile acres as far as the eye can reach, are yet denied a few door-yard flowers.

What a paradise in truth California would be if the nooks and waste spots around every home were filled with sweet-scented flowers. What lasting memories would be enshrined in the heart of every child, what beautiful thoughts and beautiful lives would unfold with every blossom.

The garden is a rare gift to man, a compensation for the troubles and despondencies of life, a place of culture for those higher senses which there alone can find the keenest pleasures. The garden furnishes a source of everincreasing and never-ending enjoyment. Here may be found an entirely natural recuperation for body and mind, a buoyancy of spirit, a calm, beautiful view of life and a relish for living which no other earthly creation can bestow.

A pleasant thoughtfulness and anticipation is awakened by the gracefully deliberate unfolding of a bud. Appreciation, a rare faculty, is cultivated by the exquisiteness of an odor. But, above all, is the sense of sight gratified. Here there is opened up a world of appreciation and artistic possibilities, which furnishes the mind with most exalted admiration. Withal, the garden brings to man a restfulness of spirit, a satisfaction in living, a broad and charitable view of life, all of which help to make him a more perfect and useful creature. 


\section{ROSES}

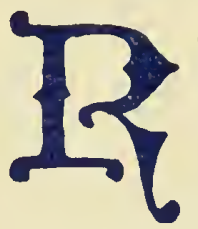

OSES attain in California a perfection which may well excite the envy of less favored regions. They lend an idealistic beauty to our gardens and a soft radiance to our oftentimes embowered houses, that go far toward mitigating the everyday cares and which furnish a source of neverending and ever-increasing enjoyment.

The wonderful size and continuous flowering of this, our garden favorite, awaken a keen sense of admiration in visitors, who ever after take delight in narrating the story of $i$ ts unequaled charms.

The very finest varieties of roses are now offered at such reasonable prices as to place them within the reach of everyone, and a very small outlay and a little fostering care will insure an abundance of the most beautiful flowers nearly the year round.

Roses easily adapt themselves to circumstances and will grow with but little care, but a healthy bush and an abundance of flowers is always the reward of generous treatment. They do best in a rich loamy or clayey soil, and can safely be planted any time from February 1st to the last of May, or in the fall. When planting cut the bushes back to sound eyes turning outward. Remove all weakly wood, spread the roots out naturally, and trim the ends of broken ones smooth. If the plant is from a pot and the ball still remains, loosen it slightly before setting in the ground. Form the soil around the plant well, being careful to surface with dry, pulverized earth. Only water when the plant shows signs of needing it, and give no fertilizer until the first growth has hardened.

None but the choicest varieties are enumerated, and none but those specially adapted to the climate and soil of California. Stock is all strong, healthy and free from insects.

Special prices on large quantities.

RAINBOW.-This new striped Tea Rose is the first rose of great merit that has been produced in California. It is a sport from Papa Gontier, and is a more robust grower and freer-flowering than its parent. The petals have great substance, and the half-open buds will often very nearly approach the Catherine Mermet in character of form. The ground color is a bright La France pink, beautifully striped and splashed with rich carmine. Price, 50c each.

\section{TEA ROSES}

Tea Roses are so universally planted in California that a special description is unnecessary. They are valued alike for their beauty of form, color and sweetness, and for their free and continuous-flowering qualities. They require more pruning when in dormant state than any other class of roses, and the flowers should not be allowed to fade upon the bushes.

Only a few of the choicest varieties are offered; strong plants from 2 and 3 inch pots. 
CATHERINE MERMET.-Clear, rosy, flesh pink, shaded and veined with amber; silver lustre, large size, magnificent buds, generally conceded to be one of the finest tea roses in existence. Price, 15c and 20c each.

MADAME HOSTE.-A fine new variety, varying in color from ivory white to cream; fine buds, free-flowering. Price, 20c and 30c each.

NIPHETOS.-Pure white, long graceful buds, delicate tea scent, freeflowering, highly prized. Price, 15c and 20c each.

PAPA GONTIER.-Crimson rose, with a lighting of yellow, buds long and fine, robust grower and free bloomer, strong tea fragrance. Price, $15 \mathrm{c}$ and $20 \mathrm{ceach}$.

PERLE DES JARDINS.-Rich straw color, sometimes deep canary, flowers and buds very large and beautiful, free-flowering, foliage very handsome; a great favorite. Price, $15 \mathrm{c}$ and $20 \mathrm{c}$ each.

SUNSET.-Rich tawny saffron and orange, similar in character of growth and flower to Perle des Jardins, of which it is a sprout; a beautiful rose. Price, $15 \mathrm{c}$ and $25 \mathrm{c}$ each.

THE BRIDE.-Pure ivory white, excepting in color identical with Catherine Mermet, its parent; buds of grand size, carried high and erect on bright, smooth stems; an all round good rose. Price, $15 \mathrm{c}$ and $25 \mathrm{c}$ each.

THE QUEEN.-A new, pure white variety of vigorous growth, flowers medium size, borne in profusion. Price, $20 \mathrm{c}$ and $35 \mathrm{c}$ each.

\section{HYBRID TEA ROSES}

The Hybrid Tea Roses, of which the La France is the original type, have been nearly all introduced in the last few years, and number of them have proven prime favorites. They are produced by crossing the Teas with Hybrid Perpetuals, the resulting varieties combining the freeflowering qualities and delicate shades of the one, with the brilliance, fragrance and vigor of the other. They do best when given a semi-seasun of rest, and should not be pruned as freely as the teas.

AMERICAN BEAUTY.-Deep, brilliant pink, shaded with carmine; buds and flowers extra large, double and exceedingly sweet; flowers borne on strong, erect stems, closely set with rich, leathery foliage. Price, 25c and $35 \mathrm{c}$ each.

DUCHESS OF ALBANY.- "Syrian rose;" an exquisite shade of clear, deep pink; a sprout of La France, similar in growth, character of flower and fragrance to its parent; one of the finest roses of recent introduction. Price, $25 \mathrm{c}$ and $3 \mathrm{c}$ each.

LA FRANCE.-Delicate, silvery rose, shading to silvery peach blossom, very large, globular form, petals sharply re-curved, delightfully fragrant and a free bloomer; a great favorite. Price, $15 \mathrm{c}$ and $20 \mathrm{c}$ each.

METEOR.-Dark, velvety crimson, exquisite buds and delicious fragrance, free-flowering; one of the finest. Price, $20 \mathrm{c}$ and $30 \mathrm{c} \mathrm{each}$.

SOUVENIR DE WOOTTON.-A beautiful shade of carmine crimson, beautiful in bud and expanded flower, sweet-scented and free-flowering; robust grower. Price, $15 \mathrm{c}$ and $25 \mathrm{c}$ each.

WM. FRANCIS BENNETT.-Brilliant crimson, long-pointed buds, delightfully fragrant, free-flowering; best for forcing and in sheltered locations. Price, $20 \mathrm{c}$ and $30 \mathrm{c}$ each. 


\section{HYBRID PERPETUAL ROSES}

The Hybrid Perpetuals are among the grandest of roses, but they do not produce their flowers as freely as other classes. Their large size, rich coloring, and sweet fragrance have, however, endeared them to the heart of every flower lover. They require strong, rich soil and bloom from the old wood.

GEN. JACQUEMINOT.-Rich, velvety crimson, large and beautiful buds and flowers; fragrance exquisite; a good grower and bloomer; an old favorite. Price, $10 \mathrm{c}$ and $20 \mathrm{c}$ each.

MAGNA CHARTA.-Clear, rosy pink, flushed with carmine, very large, globular, fragrant, strong grower. Price, $15 \mathrm{c}$ and $25 \mathrm{c}$ each.

\section{POLYANTHIA ROSES}

This class of miniature roses is exceedingly beautiful. They are of low, compact but graceful growth, and are profuee bloomers. They are conscientiously recommended to all lovers of rare and beautiful roses, and they will please all who plant them, inaking excellent borders. The weak wood should be occasionally thinned, and over-vigorous shoots stopped.

MME. CECIL BRUNNER.-Salmon pink, with rich salmon centre; exquisitely formed buds, delicately scented, profuse bloomer. Price, $15 \mathrm{c}$ and $25 \mathrm{c}$ each.

CLOTHILDA SOUPERT.-Pure white flowers, borne with wonderful freedom, regular grower, a new rose of great merit, fine for bedding. Price, $15 \mathrm{c}$ and $25 \mathrm{c}$ each.

\section{CLIMBING ROSES}

The climate of California is specially adapted to the highest development of the finest climbing roses. Only plant enough of them, and your house will be continuously wreathed in fragrant blossoms. Weak or dead wood and faded flowers should be carefully cut away. The branches should be firmly fastened with some pliable material in the way which they are desired to grow.

LAMARQUE.-Snowy white, medium size, profuse bloomer, a strong, healthy grower; the best white climber for general purposes. Price, 15c and 20c each.

MARECHAL NE IL.-Deep sulphur yellow, large and beautifully formed buds, sweet fragrance, vigorous grower. Should be planted in warm, sunny locations. Price, $20 \mathrm{c}$ and $30 \mathrm{c}$ each.

CLIMBING NIPHETOS.-P'ure white, long buds, similar to its parent Niphetos, excepting its robust climbing habit; plant in sheltered locations (new). l'rice, 35c and 50c each.

CLIMBING PERLE DES JARDINS.-Rich straw color, large and beautiful buds, of robust climbing habit; in other respects similar to its parent Perle des Jardins. A new rose of promise. Price, 35c and 50c each. 


\title{
COLLECTIONS OF ROSES
}

The following collections have been arranged to facilitate the selecting of varieties by those who are not familiar with the most desirable sorts. An opportunity is also given those who desire to secure a nice assortment at reduced rates. No particular variety or varieties are guaranteed, but whenever there accompanies the order a statement of the purpose for which the roses are desired, the collection will be made to conform as nearly as possible to the wishes of the purchaser. None but the best varieties are used in the collections.

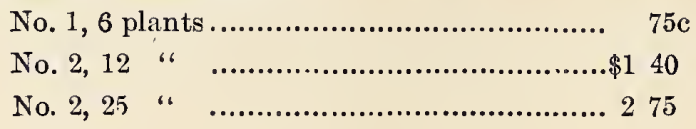

\section{CHRYSANTHEMUMS}

For centuries past the Japanese have regarded the Chrysanthemum as the idealistic flower. Gradually it has won its way in our own country until to-day it is only second to the rose in popularity. During the last few years wonderful strides have been made in the production of new varieties. Many of them being so unique and varied in color and fantastic in form, as to baffle the skill of an artist in description.

Chrysanthemums come at a time of the year when other flowers are the scarcest, even roses in the open ground having ceased to bloom. They have a flowering season extending over a period of several months, and the expanded flowers last a long time both on the bush or when cut. No garden is complete without its collection. We have taken great care to have our plants true to name and to discard all unworthy sorts.

Chrysanthemums, whether grown in pots or open ground, should have rich soil and be kept growing continuously. A sunshiny, sheltered location is best. Plenty of water should be given, and as the flowering season approaches, regular applications of weak manure water should be made. If very large show flowers are desired, cut away all side shoots, leaving only one or two of the strongest stems and as many buds. The most satisfactory way is to pinch back the small plants to induce vigorous, bushy growth; allow a number of strong shoots to remain, from which remove from one-half to two-thirds of the flower buds. The result will be an abundance of large-sized flowers.

\section{SET OF CHRYSANTHEMUMS FOR I89I}

\author{
Price, $40 \mathrm{c}$ each ; $\$ 3.75$ per set
}

ADIRONDAC.-Large, white flowers, incurved, strong grower and free bloomer; a splendid variety.

ADA SPAULDING.-Delicate shade of pink, incurved; a beautiful flower.

HARMAN PAYNE.-Deep rose, very large flower, long petals. 
HARRY E. WIDENER.-Pure, bright lemon yellow, incurved, petals crisp and stiff, long erect stems; flowers average 10 to 11 inches in diamete1 ; finest yellow for cut flowers.

JOHN THORP.-Rich deep lake, long broad petals, few tubular petals in under row, flowers large; early bloomer and vigorous grower.

MRS. ALPHEUS HARDY.-Pure white, incurved, reverse of petals thickly set with feathery-like hairs; very remarkable; a most beautiful flower.

MRS. IRVING CLARK.-Margin of petals pearly white, shading to deep rose, center beautifully whorled; large and fine.

MRS. LEVI P. MORTON.-Bright pink, base of petals white, unique appearance; should be in every collection.

MRS. FOTTLER.-Soft rose, incurved, long pointed petals; large, fine for cut flowers.

NYMPHIA.-Pure white, sweet-scented; a novelty. Good for growing in pots.

RAMONA.-Bright amber, incurved, large and full; petals or florets numerous, long, slender and tubular.

W. W. COLES. - Terra cotta, whorled center; a popular variety.

\section{GENERAL COLLECTION OF CHRYSANTHEMUMS}

Fifty plants, our selection, good varieties and colors, $\$ 6.00$

\section{WHITE VARIETIES}

BELLE POITEVINE.-White, incurved, very early. Price, $15 \mathrm{c}$ each. BRIDE.-White, incurved drooping petals; one of the best. Price, $15 \mathrm{c}$ each.

CHRISTMAS EVE.-Pure white, incurved; a good late variety. Price, $15 \mathrm{c}$ each.

CHAS. A. REESE.-Creamy white, shaded pink on inside of petals. Price, $25 \mathrm{c}$ each.

DOMINATION.-Creamy white; good size. Price, $25 \mathrm{c}$ each.

EMPRESS OF JAPAN.-White, long, graceful petals, incurved; large and beautiful. Price, 15c each.

ELSIE.-Kich creamy white. Price, $25 \mathrm{c}$ each.

FIGARO.-White, shaded with carmine. Price, $15 \mathrm{c}$ each.

INTERNATIONAL.-Ivory white, large and full. Price, $25 \mathrm{c}$ each.

JUDGE REA.-Pure white, broad petals, yellow center. Price, 35c each.

L. CANNING.-Pure white, long broad petals, free grower; one of the best. Price, $15 \mathrm{c}$ each.

MME. DREXEL-White, tinted with rose. Price, 15c each.

MME. LOUISE LE ROY.-White, incurved, creamy center, free flowering. Price, 25c each.

MARVEL. - White, maroon spot in center, a fine variety. Price, 15c each.

MISS ANNIE HARTSHORN.-Pure white, incurved, very large. Price, 25c each. 
MISS M. WANAMAKER-Creamy white, incurved, perfect ball, fine variety. Price, $25 \mathrm{c}$ each.

MOUNTAIN OF SNOW.-Pure white, large and beautiful, fine for exhibition. Price, $25 \mathrm{c}$ each.

MOLLY BAWN.-Pure white, large and irregular, beautiful. Price, $35 \mathrm{c}$ each.

MRS. LANGTRY-Pure white, outside petals quilled, very large and beautiful flowers. Price, 25c each.

MRS. M. G. THOMAS-Creamy white, incurved broad petals. Price, $15 \mathrm{c}$ each.

MRS. SAML. HOUSTON.-Pure white, incurved, large and fine. Price, 25c each.

NARRAGANSETT.-Clear white, reflexed, partly tubular center. Price, $25 \mathrm{c}$ each.

PRINCESS TECK.-White, suffused with pink, incurved. Price, 15c.

PELICAN.-Pure white, large, long, broad, curled florets, fine. Price, $15 \mathrm{c}$ each.

ROBERT BOTTOMLY.-Pure white, incurved, large and fine. Price, $25 \mathrm{c}$ each.

ROBERT BURNS.-White, incurved, large. Price, 25c each.

SUNNYSIDE.-Delicate flesh color, quilled florets, very large. Price, $35 \mathrm{c}$ each.

SNOW FAIRY.-Pure white, fine for cut flowers. Price, 25c each.

TACOMA-White, delicately tinted with pink, broad petals, perfect form. Price, $25 \mathrm{c}$ each.

\section{SHADES OF YELLOW}

BETTINA.-Clear orange, long petals, early and lasts well. Price, 15c each.

CALIFORNIA.-Rich yellow, incurved; a perfect ball, long stems, Price, 15c each.

CHEVALIER DOMAGE.-Rich golden yellow, reflexed. Price $15 \mathrm{c}$ each.

COMTE DE GERIMINY.-Nankeen yellow, large and novel. Price, $15 \mathrm{c}$ each.

EDWIN H. FITLER.-Brilliant yellow, slightly streaked with red, large and fine. Price, $25 \mathrm{c}$ each.

GOLDEN DRAGON.-Golden yellow, long twisted petals, fine. Price, ije each.

GOLD.-Pure yellow, flowers large, fine for eutting in sprays. Price, 15c each.

GRANDIFLORUM.-Pure golden color, petals broad, incurved, solid ball, fine variety. Price, $25 \mathrm{c}$ each.

HENRY CANNELL.-Golden yellow, incurved, ball-shaped, early. Price, 25c each.

JARDINE DES PLANTES.-Dazzling yellow, medium size. Price $15 \mathrm{c}$ each.

JOHN COLLINS.-Yellow, orange shading, large and full. Price, 15c each. 
JOHN WEBSTER.-Light orange. Price, 15c each.

KIOTA.-Deep yellow, incurved, large. Price, 15c each.

MRS. RICHARD ELLIOTT.-Bright yellow, incurved. Price, $15 \mathrm{c}$ each.

MAGICIENNE.-Light lemon color, tubular petals, large, spreading flowers, early. Price, $15 \mathrm{c}$ each.

MRS. C. H. WHEELER.-Orange yellow, outer side of petals, crimson, flowers very large and heavy. Price, $15 \mathrm{c}$ each.

MRS. J. N. MAY.-Clear bright yellow, incurved, broad, thick florets. Price, 25c each.

MONADONOCK.-Bright yellow, tubular florets; fine. Price, $15 \mathrm{c}$ each.

MRS. A. G. BURPEE. - Yellow, reflexed petals. Price, $25 \mathrm{c}$ each.

MRS. I. C. PRICE.-Rich chrome yellow, petals gracefully incurved. Price, 40c each.

MISS MARY WEIGHTMAN.-Chrome yellow, loose feathery form, large and full. Price, $25 \mathrm{c}$ each.

MRS. A. WATERER.-Rich yellow, base of petals pink. Price, 35c each.

MRS. WINTHROP SARGEANT,-Bright straw color, incurved, long stems. Price, 40c each.

MRS. W. K. HARRIS.-Rich chrome yellow; one of the finest yellows. Price, 25c each.

NEESIMA.-Pure golden yellow, incurved; late. Price, 35c each.

PETER THE GREAT.-Lemon yellow, large flat, incurved florets. Price, $15 \mathrm{c}$ each.

SACHEM.-Clear yellow, strong grower, reflexed flowers.

SUZON.-Clear orange, reflexed petals. Price, $15 \mathrm{c}$ e:ch.

SOURCE D'OR.-Orange gold shading, twisted recurved petals. Price, 15c each.

THORNBURG.-Primrose yellow, long-pointed petals, incurved. Price, $25 \mathrm{c}$ each.

THOMAS CARTHAGE.-Lemon yellow, a fine variety. Price $25 \mathrm{ceach}$.

VIEIL OR.-Deep yellow, fine large flotrers. Price, $15 \mathrm{c}$ each.

W. H. LINCOLN.-Golden yellow, flat spreading petals of great substance, very large, incurved. Price, 35̃e each.

YELLOW BIRD.-Soft yellow, long petals. Price, 40c each.

\section{SHADES OF PINK}

CERES.-Pink; a fine variety. Price, $15 \mathrm{c}$ each.

EXCELLENT.-Rosy pink, large flowers; fine for cutting. Price, 25c each.

ELK'S HORN.-Rich peach color, incurved, segregated petals; very fine. Price, $25 \mathrm{c}$ each.

FRED HART.-Peach color, incurved, large. Price, 15c each.

J. N. GERARD.-Pink; one of the best of its color. Price, $15 \mathrm{c}$ each.

JOHN HUGHES.-Light pink. Price, $15 \mathrm{c}$ each. 
JOHN LANE.-Rosy pink, lighter shadings, ends of center petals tipped with gold; a perfect pink ball. Price, 40c each.

LADY SLADE.--Soft lilac pink, blush center, incurved, 15c each.

LILLIAN B. BIRD.-Beautiful shade of pink, very large, tubular petals; one of the best. Price, 25c each.

MRS. A. BLANC.-Rich lavender, inside florets, erect, strong grower. Price, 15c each.

MRS. DE WITT SMITH. -Soft rose shading to white center, incurved; large and fine. Price, $15 \mathrm{c}$ each.

MALIBRAN.-Soft rose changing to white, incurved. Price, 15c each.

MRS. HICKS ARNOLD.-Soft rosy pink, large, early, fine foliage. Price, 15c each.

MRS. MARY MORGAN.-Soft blush; beautiful perfect flower. Price, $35 \mathrm{c} \mathrm{each}$.

NEWPORT.-Clear rose pink, large beautiful flowers, opening flat; fine. Price, 25c each.

PHILIPPE LACROIX.-Soft rose shading to white center; large and fine. Price, $20 \mathrm{c}$ each.

PRES. ARTHUR.-Rose, flowers very large, petals opening in whorles. Price, 20c each.

ROSE QUEEN.-Bright rose, a fine variety. Price, $35 \mathrm{c}$ each.

SHAKES PIERLE.-Pink, shaded with white. Price, $15 \mathrm{c}$ each.

T. C. PRICE.-Strawberry, cream color, petals twisted, incurved, large. Price, 25c each.

ROBERT CRAIG.-Rosy pink, very large; a splendid flower. Price, $25 \mathrm{c}$ each.

\section{SHADES OF RED}

CONQUETE.-Indian red; beautiful plant. Price, $15 \mathrm{c}$.

CAP UCINE.-Vermilion, incurved; good early variety. Price, 15c each.

CROWN PRINCE.-Maroon red, shaded with gold, incurved; fine. Price, 25c each.

CULLING FORDII.-Brilliant crimson, under side of petals old gold; one of the finest. Price, $25 \mathrm{c}$ each.

DELIA. Dull red and yellow, tubular petals, round fowers. Price, $15 \mathrm{c}$ each.

E. W. CLARK.-Rich peony red; large and fine. Price, $15 \mathrm{c}$ each.

EDWARD LONSDALE.-Dark velvety red, large size, good habit; one of the best. Price, $25 \mathrm{c}$ each.

EDWIN MOLYNEUX.-Rich chestnut crimson, reverse of petals golden, florets broad, incurved at points. Price, $25 \mathrm{c}$ each.

G. F. MOSEMAN.-Bright terra cotta and buff, incurved, large flowers. Price, 15c each.

J. G. BLAINE.-Rich dark maroon, slightly incurved. Price, 15c each.

LA TOSCA.--Deep brownish red. Price, $15 \mathrm{c}$ each. 
MRS. WM. HOWELL.-Crimson, reflexed; fine for pot culture. Price, $25 \mathrm{c}$ each.

MRS. CONEZIE.-Velvety red, incurved, large, broad petals. Price, $25 \mathrm{ceach}$.

MONTEZUMA.-Light red, outer side of petals striped with gold, yellow center. Price, $15 \mathrm{c}$ each.

MRS. J. T. EMLIN.--Blood red on upper side of petals, reverse old gold. Price, 15c each.

MONTAUK.-Crimson maroon, Hat petals showing yellow center, large. Price, 15c each.

MRS. A. HAIG.-Dark red, large, full in center. Price, 40c each.

MRS. WM. BOWEN.--Red and gold, free grower and bloomer. Price, 25c each.

MRS. GEORGE.--Dark red, good grower. Price, 15c each.

OCEOLA.-Bright red, reverse pale yellow, twisted petals, large irregular flower. Price, $15 \mathrm{c}$ each.

ROTHWELL HYDE.-Red, shaded with yellow, large flowers. Price, $40 \mathrm{c}$ each.

STARS AND STRIPES.-Carmine, large flowers. Price, 25c each.

TOKIO.-Bright red, showy, large flowers. Price, $15 \mathrm{c}$ each.

W. W. COLES.--Brick red, whorled center, fine flowers. Price, 40c each.

\section{CARNATIONS}

Carnations are so universally planted and admired that a general description seems hardly necessary. They are so easily grown in all parts of California, embrace such a diversity of beautiful shades and colors, and have such a delightful fragrance, that no garden is complete without its bed or border of carnations.

We take particular pride in our collection, which is the choicest to be found in California. Only those varieties are offered which have been thoroughly tested, and are adapted to general planting.

Carnations will thrive in any good garden soil, the richer the better, but fertilizers should never be brought in direct contact with the plants. Long, straggly shoots or over-vigorous growths should be stopped by pinching until a strong, bushy, symmetrical plant is formed, when flower shoots may be allowed to grow; give plenty of water when growing vigorously and when flowering.

We offer the following from $2 \frac{1}{2}$ in. and $4 \frac{1}{2}$ in. pots:

B. A. ELLIOTT.-Brilliant vermilion, scarlet. Price, $10 \mathrm{c}$ and $15 \mathrm{cech}$.

BUTTERCUP.-Deep sulphur yellow, slightly penciled with carmine, free bloomer, a standard sort. Price, 20c each.

BLACK KNIGHT.-Very dark crimson, nearly black sometimes, one of the best of the dark varieties. Price, $20 \mathrm{c}$ each. 
COL. P. WILDER.-Deep rich scarlet, large and fine. Price, $20 \mathrm{c}$ each.

FERDINAND MANGOLD.-Bright dark red, large and beautiful flowers. Price, $15 \mathrm{c}$ each.

GRACE WILDER.-Soft shade of rosy pink; one of the most beautiful of the pink carnations. Price, $10 \mathrm{c}$ and $15 \mathrm{c}$ each.

HEINZE'S WHITE.-Pure white, large flowers, free bloomer, one of the best. Price, $10 \mathrm{c}$ and $15 \mathrm{c}$ each.

J. J. HARRISON.-Pearly white, delicately streaked with rosy carmine, petals edged with carmine, fine grower and bloomer. Price, 10c and 15c each.

L. L. LAMBORN,-Pure white, flowers deeply fringed and of immense size; calyx does not burst; very free bloomer, one of the best. Price, $10 \mathrm{c}$ and $20 \mathrm{c}$ each.

LU LU.-Pretty shade of pink, fine for growing in pots. Price, $10 \mathrm{c}$ and $15 \mathrm{c}$ each.

PORTIA.-Intense flaming scarlet, vigorous grower, flowers freely produced on long stems; one of the best. Price, $10 \mathrm{c}$ and $15 \mathrm{c}$ each.

PRESIDENT GARFIELD.-Beautiful crimson scarlet, very large flowers; a fine variety. Price, $10 \mathrm{c}$ and $15 \mathrm{c}$ each.

PRIDE OF PENHURST.-Pure sulphur yellow, large, very double. 10c each.

ROBERT CRAIG.-Brilliant scarlet, fine grower, good-sized flowers. Price, $10 \mathrm{c}$ and $15 \mathrm{c}$ each.

STARLIGHT.-Primrose yellow, a novel color; a beautiful variety.. Price, 10c and $15 \mathrm{c}$ each.

SUNRISE.-Orange, flaked with crimson, very large and beautiful, does not burst its calyx, long stems. Price, $20 \mathrm{c}$ each.

SPRINGFIELD.-An exquisite shade of delicate pink, very pretty and sweet. Price, $10 \mathrm{c}$ and $15 \mathrm{c}$ each.

WILLIAM SWAYNE.-White, a fine free bloomer, 10c and 15c each.

\section{PELARGONIUMS}

Pelargoniums, or Lady Washington Geraniums, as they are sometimes called, grow and blossom with remarkable luxuriance in California, particularly in the coast counties. They furnish, at nearly all seasons of the year a profusion of flowers whose unique colorings it is most difficult to describe. Pelargoniums are among the most satisfactory flowers that can be planted, as they grow vigorously for years, and require but little care when once established.

Plant in warm, sunny, well-drained locations, in good soil, pinch in overvigorous shoots to keep the plant symmetrical. Keep faded flowers cut off and give water sufficient to keep them growing.

All of the varieties offered are so beautiful that it may prove quite difficult to select a few sorts. 
The whole collection will be sent at the reduced rate of $\$ 6.00$; price, single plants, 40 cents each. Stock on hand is extra large and fine, but is in limited supply. Orders will be booked for younger stock for Fall delivery at much reduced prices.

BEAUTY OF OXTON.--Upper petals, rich maroon; lower petals, dark crimson, maroon shading, light center; petals, crimperl, edged with white.

BEADSMAN.-

DOCTOR MASTERS.-Upper petals, nearly black, shading to rich crimson margin; lower petals, small blotch, broad margin.

DUCHESS OF BEDFORD.-Pure white, delicately veined and shaded with clear rose.

DAVID NULLY.-

EMPRESS OF INDIA.-White, shaded with rose; large flower.

GLORIE DE TOURS.-Orange, with large, dark blotches.

GLORIA PATRIA.- White ground, crimson shadings on upper petals.

GOLDEN GATE. - A California variety of great merit.

LOUISE ORNER. - White, with delicate wine-red shadings.

LORD CLYDE.-

MRS. JOHN SAUL.-Rich glowing vermilion, light center; light margin to petals ; large trusses.

MDE. EVERARD.-Rich crimson, a most desirable cort.

MME. THIBAUT.-White ground, richly blotched with crimson.

MRS. COUPLAND.-Perle white, very slight purple veins in upper petals, a magnificent sort.

PRINCE OF PELARGONIUMS.-Soft, clear pink ground, with maroon blotches.

PRINCE OF WALES.-Bright vermilion, with light center and edges, very free-flowering.

QUEEN VICTORIA. Rich vermilion, petals broadly margined with pure white, the upper blotched with bright maroon; petals, peculiarly crispy, giving appearance of being double.

\section{VIOLETS}

The sweet, modest Violet has won a warm place in the affections of the American people. It is particularly popular in California on account of the ease with which it can be grown, the large size and abundance of the flowers produced and the long flowering season.

Our violet fields, a view of which is given in the frontispiece, are acres in extent, and are conceded to be the largest and finest in the United States.

Violets delight in a partially shaded location and during the growing and blooming season should not lack for water. If large fine flowers are desired, the plants must be given plenty of room and kept free from runners. All of the varieties make pretty borders.

Strong, healthy plants. Price per doz., $50 \mathrm{c}$, per $100, \$ 3.00$. 
SWANLEY WHITE.-Finest double white, very sweet; should be given more sunlight than the purple varieties, as the flowers are liable to a greenish tint when too much shaded.

MARIE LOUISE.-Dark purple, very large, double and sweet, profuse kloomer, and regarded by many as the finest of all double violets.

NEAPOLITAN._Light purple, large, double and deliciously sweet, profuse bloomer.

THE CZAR (Russian).-Single purple, very dark and sweet; vigorous grower, flowers borne on long, erect stems ; preferred by some to any uther violet.

\section{SWEET PEAS}

Sweet Peas have justly been classed among the most artistically beautiful and sweetest of flowers. To foster the growing taste and meet the popular demand for this beautiful flower, we have at considerable trouble and expense collected all of the newest and best varieties from both Europe and the United States. So great has the demand grown for our unrivalled collection that 3 to 5 acres are annually devoted to their culture.

Only a few of the choicest varieties are offered in the appended list. These Sweet Peas should not be confounded with the ordinary stock sorts sold by seedsmen. None need hesitate to order, as their great beauty, size, sweetness and vigor of growth cannot fail to give the greatest satisfaction. Sow the seed in good garden soil from October to April at intervals for a succession of flowers. Do not allow them to suffer for water and give some slight support. Do not allow flower spikes to go to seed, as it will greatly shorten the flowering season.

Price of seed, named varieties, 25c per packet. $\$ 2.50$ per set of 12 varieties. Mixed, named varieties, $30 \mathrm{c}$ per oz. All sorts, $15 \mathrm{c}$ per oz.

ALBA MAGNIFICA.-Pure white, very chaste and beautiful.

BUTTERFLY.-White and lilac, very pretty.

BOREATTON.-Dark crimson purple, wings shaded with rose.

CROWN PRINCESS OF RUSSIA.-Clear, delicate pink.

CARDINAL.-Crimson scarlet, fine grower and bloomer.

DUCHESS OF EDINBURGH.-Light scarlet and crimson, marbled and splashed with creamy white.

FAIRY QUEEN.-White and rose, delicate shade.

ISA ECKFORD.-Creamy white, suffused with rusy pink.

NELLIE JONES.- White and light pink, exquisitely delicate.

ORANGE PRINCE.-Orange pink, flushed with scarlet.

PRINCESS OF WALES.-White ground, shaded and striped mauve.

THE QUEEN.--Rosy pink and light mauve; a charming contrast of colors. 


\section{PALMS}

There is certainly no class of plants which adds so much to the tropical beauty of California gardens as the stately but ever-graceful palms. They should be planted in good soil, and given plenty of water the first year until the roots become established. The ground should be occasionally loosened and pulverized.

CHAM EROPS EXCELSA.-An upright, symmetrical-growing fan palm, deeply notched leaves, hardy; one of the finest lawn decorative plants. Price, 25c each, $\$ 20.00$ per 100 .

PHCENIX (Date Palm)-Several varieties of this most graceful palm are offered; all of them have long, recurved, pinnate fronds, and are hardy. Price $50 \mathrm{c}$ and $\$ 1.00$ each.

SEAFORTHIA ELEGANS.-One of the most graceful decorative plants for the conservatory or for very warm, sheltered locations in the open ground; fronds broadly pinnated and of a rich green color. Price, $\$ 1.00$ each.

PRITCHARDIA FILIFERA.-Our native California palm, very large, deep green, fan-shaped leaves; rapid grower and hardy; fine for avenue planting or as single specimens on the lawn.

Price of strong plants (4 inch pots) $25 \mathrm{c}$ each, $\$ 20.00$ per 100. Large plants from open ground, $\$ 25.00$ per 100 .

PALM SEEDS.--Varieties and prices upon demand.

\section{FERNS}

Ferns are a beautiful class of plants that are each year increasing in public estimation. Indeed there are but few more beautiful sights than well grown specimen ferns, possessing, as they do, the highest order of graceful delicacy of foliage.

The varieties offered should be grown in pots in shaded or partly shaded locations, and should be kept constantly moist without having the soil soggy. They should be allowed a season of rest, the proper time being indicated by the foliage.

Fine, large plants, prices upon application.

ADIANTUM CUNEATUM.-The very best variety for general purposes, large, beautiful fronds, fine for cutting.

ADIANTUM FARLEYENSE.-This may be called the queen of maiden-hair ferns, pinnules are large and delicate, and of an exquisite shade of soft pale green, large and graceful fronds. 


\section{DECIDUOUS AND EVERGREEN TREES}

The Nurseries offer some of their ornamental trees which are catalogued below, which, as it is desired to make room for other stock, are offered at a low rate.

Most of these trees have been transplanted from the seedbed into the open ground, which adds strength to the tree and makes its growth more certain.

All evergreens are taken up with balls.

\begin{tabular}{|c|c|c|c|}
\hline & Each & Per 10 & $\begin{array}{l}\text { Per } \\
100\end{array}$ \\
\hline 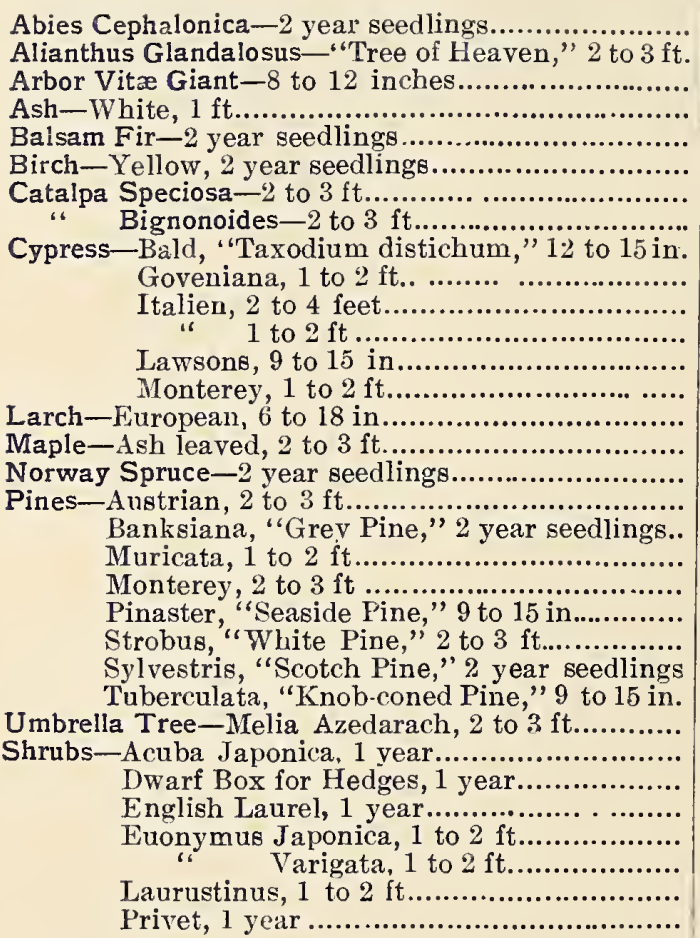 & $\begin{aligned} \$ 025 \\
20 \\
30 \\
10 \\
25 \\
\\
20 \\
20 \\
20 \\
10 \\
30 \\
20 \\
15 \\
15 \\
10 \\
10 \\
25 \\
25 \\
15 \\
15 \\
20 \\
10 \\
25 \\
10 \\
10 \\
20\end{aligned}$ & $\begin{array}{rrr}\$ & 2 & 00 \\
1 & 50 \\
2 & 50 \\
& 75 \\
2 & 00 \\
& & \\
1 & 50 \\
1 & 50 \\
1 & 50 \\
& 75 \\
2 & 50 \\
1 & 50 \\
1 & 25 \\
1 & 00 \\
& \\
& 75 \\
2 & 00 \\
2 & 00 \\
1 & 00 \\
1 & 00 \\
1 & 50 \\
& 75 \\
2 & 00 \\
75 \\
& 75 \\
1 & 50\end{array}$ & $\begin{array}{rr}10 & 00 \\
10 & 00 \\
3 & 00 \\
10 & 00\end{array}$ \\
\hline
\end{tabular}




$$
\text { , }
$$

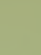

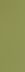

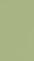


